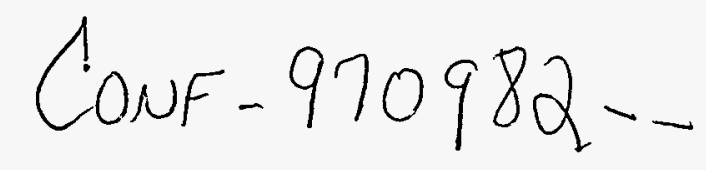

LA-UR-97- 3164

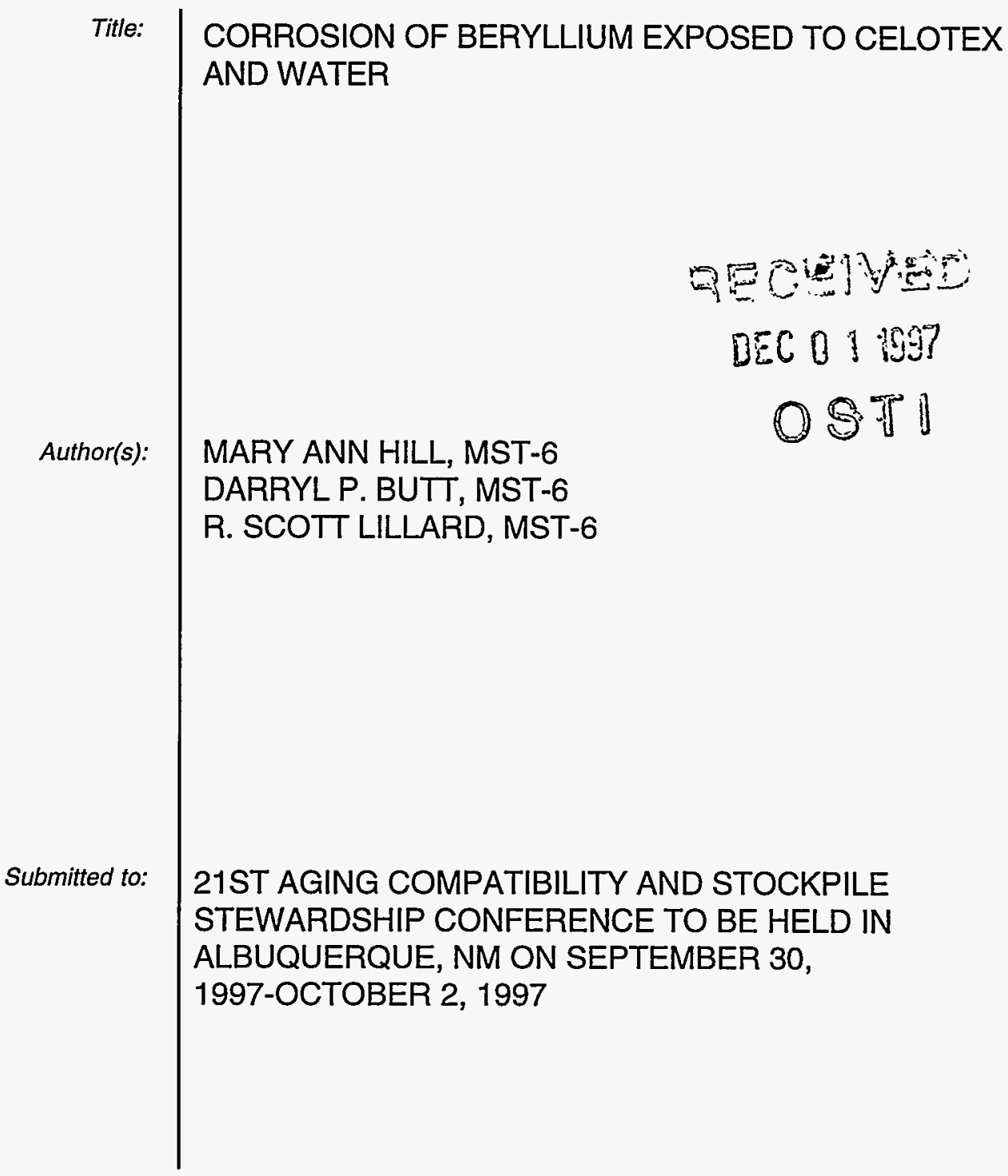

MASTER

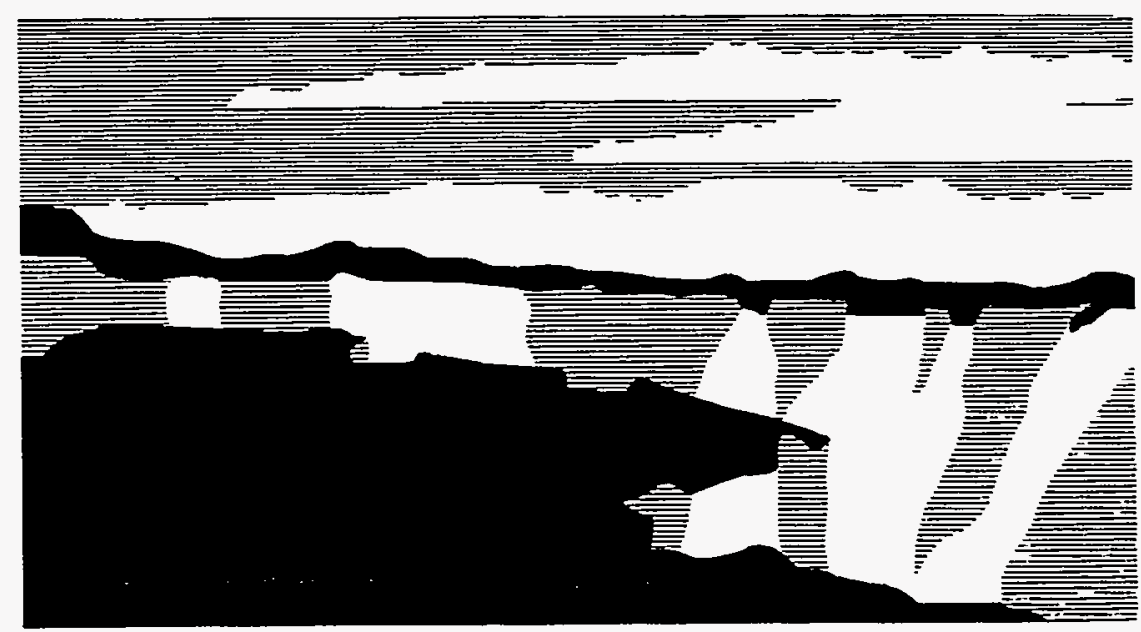

Los Alamos National Laboratory, an affirmative action/equal opportunity employer, is operated by the University of California for the U.S. Department of Energy under contract W-7405-ENG-36. By acceptance of this article, the publisher recognizes that the U.S. Government retains a nonexclusive, royalty-free license to publish or reproduce the published form of this contribution, or to allow others to do so, for U.S. Government purposes. The Los Alamos National Laboratory requests that the publisher identify this article as work performed under the auspices of the U.S. Department of Energy. 


\section{DISCLAIMER}

This report was prepared as an account of work sponsored by an agency of the United States Government. Neither the United States Government nor any agency thereof, nor any of their employees, makes any warranty, express or implied, or assumes any legal liability or responsibility for the accuracy, completeness, or usefulness of any information, apparatus, product, or process disclosed, or represents that its use would not infringe privately owned rights. Reference herein to any specific commercial product, process, or service by trade name, trademark, manufacturer, or otherwise does not necessarily constitute or imply its endorsement, recommendation, or favoring by the United States Government or any agency thereof. The views and opinions of authors expressed herein do not necessarily state or reflect those of the United States Government or any agency thereof. 


\section{DISCLAMMER}

Portions of this docament may be illegible in electronic image produets. Images are produced from the best available original document. 


\title{
Corrosion of Beryllium Exposed to Celotex and Water
}

\author{
Mary Ann Hill, Darryl P. Butt, and R. Scott Lillard, \\ Materials Corrosion and Environmental Effects Lab, Group MST-6 \\ Los Alamos National Laboratory \\ Los Alamos, New Mexico 87545
}

\section{Introduction}

Celotex is a commercial rigid cellulose fiberboard product primarily used in the building construction industry. Currently celotex is being used as a packing material in AL-R8 containers. Ion chromatography of celotex packing material at Lawrence Livermore National Laboratory (LLNL) has indicated that this material contains aggressive anions, including chloride, which may accelerate corrosion (1). It is well known that beryllium is susceptible to pitting corrosion when exposed to chloride containing environments. Levy (2) noted pitting in beryllium at the open circuit potential when exposed to $0.1 \mathrm{M} \mathrm{NaCl}$ solution. This investigation attempts to evaluate the potential risk of accelerated beryllium corrosion from celotex and water which may occur naturally when celotex dust comes into contact with moisture from the atmosphere.

\section{Experimental Methods}

The celotex packing material analyzed in this investigation was composed of approximately $80 \mathrm{wt} \%$ sugar cane fiber, $10 \%$ paper, $10 \%$ starch, and a wax emulsion. The manufacturing process is a wet slurry process in which no added chlorine is used in the processing. Aluminum sulfate is added to the slurry to precipitate the wax emulsion. The original specifications for storage in the AL-R8 container call for a grade of material which complied with ASTM C208 and C209. In order to obtain a sufficient amount of liquid for electrochemical testing and to insure as much of the water soluble components in celotex were extracted as possible, 111 grams of celotex were ground and then soaked in $700 \mathrm{ml}$ of deionized water for approximately three weeks. A Buchner funnel was used to extract the supernatant liquid from the celotex. Of the original $700 \mathrm{ml}$ of water, $250 \mathrm{ml}$ was extracted and subsequently diluted with $125 \mathrm{ml}$ of deionized water to yield a total of $375 \mathrm{ml}$ of liquid. The $\mathrm{pH}$ of this solution was 4.0. Approximately $370 \mathrm{ml}$ of this was used for electrochemistry experiments. This solution was deaerated in high purity argon for three days prior to immersing the sample. The remaining $5 \mathrm{ml}$ of solution was analyzed for chloride and fluoride using ion chromatography (IC). To facilitate the IC analysis, the solution was diluted prior to analysis (1 part solution to 10 parts deionized water).

Potentiodynamic polarization curves were run at a scan rate of $0.1 \mathrm{mV} / \mathrm{sec}$. A $5.3 \mathrm{~Hz}$ low pass filter was used to minimize noise. A saturated calomel electrode (SCE) was used for the reference electrode and a platinum mesh for the counter electrode. The S200F beryllium working electrode had a surface area of $1.43 \mathrm{~cm}^{2}$ and was polished with 400 grit $\mathrm{SiC}$ paper prior to testing. Electrochemical measurements were made using commercially available hardware and software. To insure steady state, samples were left at the open circuit potential for one hour prior to running the polarization curves.

\section{Results and Discussion}

Lawrence Livermore National Laboratory conducted an IC analysis of the celotex and found that the chloride concentration was $0.94 \mathrm{~g} \mathrm{Cl} / \mathrm{kg}$ celotex. To determine the precise concentration of $\mathrm{Cl}^{-}$and $\mathrm{F}$ in our solution, IC analysis was performed at LANL on the $5 \mathrm{ml}$ aliquot removed prior to testing the beryllium. The actual chloride concentration of the solution was determined from the initial and dilution volumes. The chloride concentration, $0.0077 \mathrm{M}$, was calculated to be $1.7 \mathrm{~g} \mathrm{Cl} / \mathrm{kg}$ celotex. The fluoride concentration, $0.0074 \mathrm{M}$, was calculated to be $0.89 \mathrm{~g} \mathrm{~F} / \mathrm{kg}$ celotex.

The difference between the $\mathrm{Cl}^{-}$and $\mathrm{F}^{-}$concentrations determined in the LLNL IC analysis and those determined at LANL likely owes to the differences in the extraction methods. The 
celotex at LANL was shredded into $0.5-2 \mathrm{~cm}$ size pieces, and allowed to soak in solution for nearly three weeks prior to use. In the LLNL method, the sample sizes were 5-10 grams and no mention of the grinding/shredding of celotex was reported. Further, the samples only soaked in solution for two hours prior to IC analysis. Thus, the smaller particle sizes and longer soak times likely allowed more of the free available chloride to soak into solution.

Microbial analysis of the celotex solution found a high concentration of the bacteria diptheroids bacillus. This bacteria is a commonly found airborne species. It has not been determined if the bacteria originated in the celotex, but their ability to reproduce was aided by the sugar cane in the celotex. Further, it is not clear whether the presence of this bacteria increases the corrosion rate of beryllium.

The open circuit potential (OCP) as a function of time for S200F beryllium in the deaerated celotex solution is presented in Figure 1. As the OCP rises to $-0.88 \mathrm{~V} \mathrm{SCE}$, transients in the potential time curve not observed at lower potentials begin to appear. These potential/time transients at longer immersion times are an indication of pitting corrosion. Visual inspection of the beryllium sample revealed localized corrosion sites indicative of pitting corrosion.

A typical potentiodynamic polarization curve showing corrosion behavior of beryllium celotex solution is shown in Figure 2. It is characterized by large changes in current density for small changes in the applied potential, at all potentials above the open circuit potential. In comparison, potentiodynamic polarization curves showing the behavior of beryllium in 0.01 $\mathrm{M} \mathrm{NaCl}, 0.01 \mathrm{M} \mathrm{NaF}$, and a combined $0.01 \mathrm{M} \mathrm{NaCl} / 0.01 \mathrm{M} \mathrm{NaF}$ solution are also shown in Figure 3. It can be seen that the electrochemical behavior of beryllium in celotex most closely resembles the $0.01 \mathrm{M} \mathrm{NaCl}$ solution. Pitting of the beryllium did not occur when exposed to the $0.01 \mathrm{M} \mathrm{NaF}$. However, pitting has been observed in more dilute $\mathrm{NaF}$ solutions (less than $0.001 \mathrm{M})$. For beryllium in the celotex solution, large changes in the current density were measured for very small changes in the applied potential at all potentials above the OCP.

The theoretical pitting potential for beryllium in a solution containing $0.0077 \mathrm{M}$ chloride is $-0.864 \mathrm{~V} \mathrm{SCE}$. This value was calculated using the linear fit for the plot in Figure 4 . This value compares well with the observed pitting potentials of approximately $-0.850 \mathrm{~V}$ and $-0.870 \mathrm{~V} \mathrm{SCE}$ and the theoretical line shown in Figure 4. However, the theoretical pitting potential calculated from the $\mathrm{LLNL} \mathrm{Cl}$ concentration analysis does not compare well with the measured pitting potential. The values from LLNL are approximately $50-75 \mathrm{mV}$ more negative than the observed pitting potentials for beryllium in $\mathrm{Cl}^{-}$. More negative values are consistent with an underestimation of chloride concentration.

\section{Conclusions}

These results indicate that storage conditions which may expose beryllium to a combination of celotex and moisture will result in pitting corrosion of the beryllium. Currently we are investigating the exact atmospheric conditions (i.e. temperature, humidity, celotex dust levels) which will result in pitting corrosion of beryllium. This is being accomplished with an atmospheric corrosion chamber which can simulate storage conditions.

\section{References}

1. "Extraction Analysis of Celotex Packing Material", James D. LeMay, Lawrence Livermore National Laboratory, April 14, 1995.

2. D. J. Levy, The Electrolytic Polarization of Beryllium, Lockheed Missiles and Space Technical Report No. 6-90-61-75, (1961). 


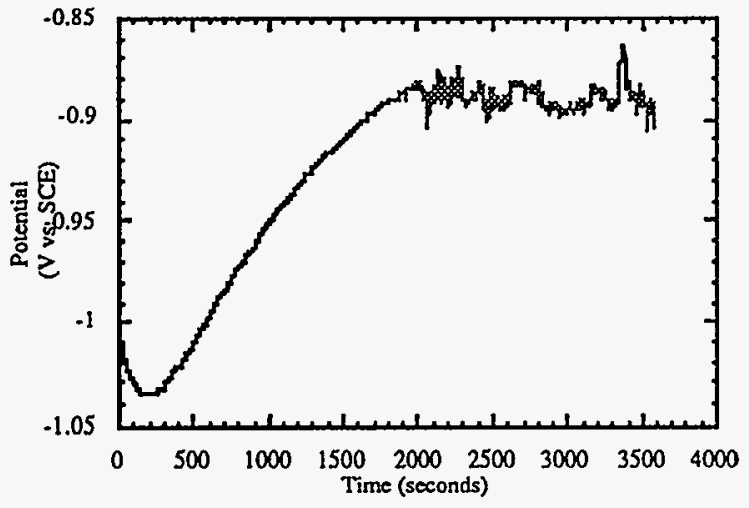

Figure 1. Open circuit potential as a function of time for S200F beryllium in celotex solution.

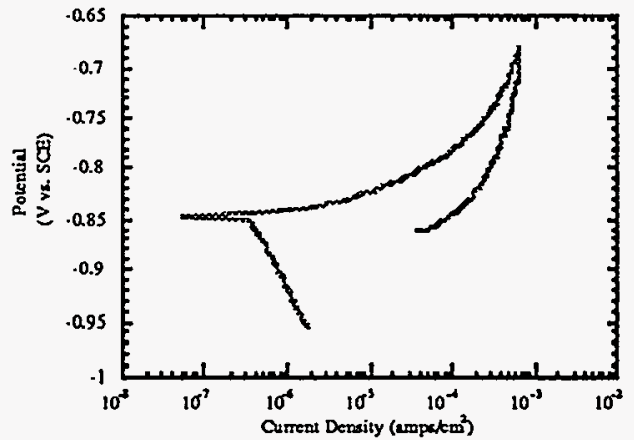

Figure 2. Potentiodynamic polarization curve for S200F Be in celotex solution.

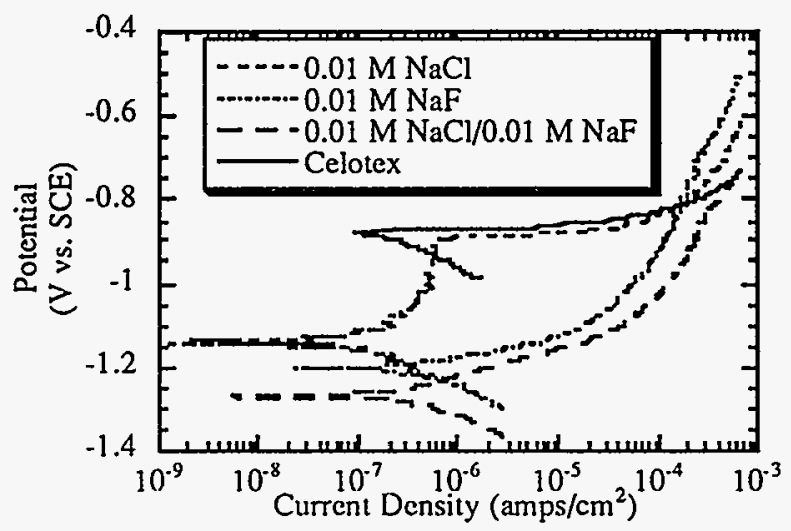

Figure 3. Potentiodynamic polarization curves for S200F beryllium. All solutions were deaerated and kept at ambient temperature.

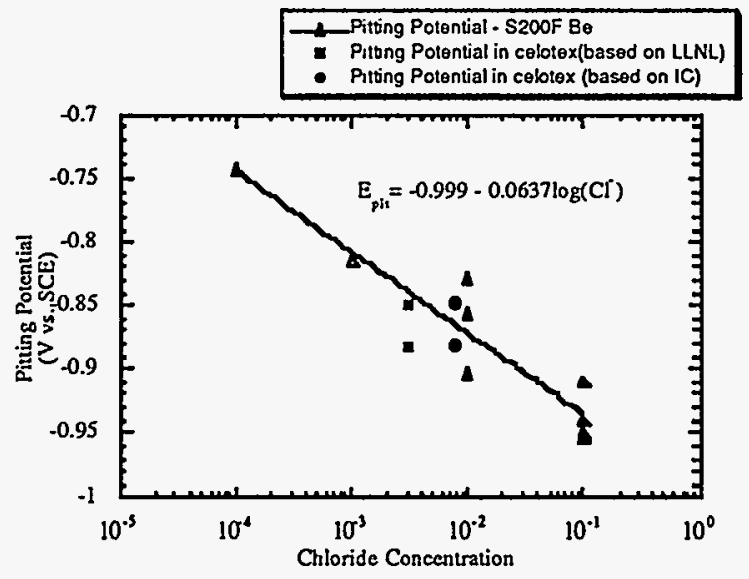

Figure 4. Pitting Potential for S200F beryllium as a function of chloride concentration. Measurements made in deaerated $\mathrm{NaCl}$ at ambient temperature. Graph also presents pitting potential observed in celotex solution based on both LLNL and LANL calculations of chloride concentration. 